\title{
Synthesis of 1-phenyl-3, 4-dihydropyrimidine-2(1H)-ones derivatives under solvent free condition and their antimicrobial activity
}

\author{
K. Akhter ${ }^{1}$, K. Jahan ${ }^{1}$, M. E. Halim ${ }^{1}$, S. Shefa ${ }^{1}$, S. Rifat ${ }^{1}$, K. R. Khan ${ }^{1}$, S. M. Ahmed ${ }^{2}$ and U. K. R. Romman ${ }^{1 *}$ \\ ${ }^{I}$ Department of Chemistry, University of Dhaka, Dhaka-1000, Bangladesh \\ ${ }^{2}$ Department of Chemistry, American International University-Bangladesh, Khilkhet, Dhaka-1229, Bangladesh
}

Received: 03 January 2018

Revised: 06 June 2018

Accepted: 03 December 2018

DOI: https://doi.org/10.3329/bjsir.v54i1.40730

\begin{abstract}
We report herein the use of nickel nitrate hexahydrate $\left[\mathrm{Ni}\left(\mathrm{NO}_{3}\right)_{2} \cdot 6 \mathrm{H}_{2} \mathrm{O}\right]$ as a new catalyst for the one-pot Biginelli like reaction coupling of 1-phenyl thiourea, ethyl acetoacetate and aromatic aldehydes to afford the corresponding 1-phenyl-3,4-dihydropyrimidin-2(1H)-thiones under solvent free condition to avoid the usage of hazardous organic solvents. The synthesized compounds were evaluated for their antimicrobial activity by KIRBY-BAUER disk diffusion method. Most of the compounds showed good to moderate antimicrobial activity.
\end{abstract}

Keywords: Nickel nitrate hexahydrate; 1-Phenyl thiourea; Aldehydes; Ethyl acetoacetate; Biginelli reaction; Antimicrobial activity

\section{Introduction}

Pyrimidines and their derivatives play an important role in human vital functions. The pyrimidine skeleton is the component of a series of natural compounds (vitamin B1, nucleic acids), chemotherapeutic drugs (Flurouracil) and synthetic medicines (Barbiturates). The biological importance of pyrimidine derivatives caused a significant interest in their synthesis (Cho et al., 1989; Mirzaei et al., 2001; Shaaban et al., 2008). Dihydropyrimidines (DHPMs) and their derivatives are pharmaceutically important as Calcium channel blockers, $\alpha$ 1-1-a-antagonists, antihypertensive agents, inhibitors of the fatty acid trans-porter, and mitotic kinesin inhibition (Rovnyak et al., 1995; Van Zandt et al., 2005). These compounds have also been found to posses antiviral, antitumor and antibacterial properties (Tsuruo et al., 1983). Moreover, the biological activity of some isolated marine natural products and alkaloids have been attributed to the Dihydropyrimidine moiety (Snider and Shi, 1993). For example, the anti-cancer agent monastrol (Fig. 1) has been shown to specifically affect mitosis via a new mechanism consisting of the specific and reversible inhibition of the motility of the motor protein mitotic kinesin (Dondoni et al., 2002). Since more than one hundred years, Biginelli suggested a dihydropyrimidine ring construction based on the use of $\beta$-dicarbonyl compounds as a source of two carbon fragment with aldehydes and urea or thiourea as an N-C-N fragment (Biginelli, 1893).

It is worth mentioning that Biginelli reaction is one of the most named reactions and his collaboration is still considered one of the important pyrimidine synthesis. In the past 10 years, several one-pot methodologies for the synthesis of DHPM derivatives were developed and several modifications have been introduced. Most of them are based on Lewis acid-catalyzed reactions (Paraskar et al., 2003; Sabitha et al., 2005; Azizian et al., 2006; Sadek et al., 2010; Shapiro and Vigalok, 2008; Chitra and Pandiarajan, 2009; Mandhane et al., 2010; Salim and Akamanchi, 2011) which permits the reaction to proceed under milder conditions and with higher yields, than those outlined by Biginelli in the original procedure. Microwave irradiation has also proved beneficial (Pasunooti et al., 2011). 
Natural acidic catalysts have been also utilized (Patil et al., 2011). Very recently, Biginelli reaction has been conducted under basic conditions. This involves the use of $\mathrm{PPh}_{3}$, under solvent free conditions (Debache et al., 2008), $t$-BuOK at $70^{\circ} \mathrm{C}$ (Shen et al., 2010), chiral primary amines (Ding and Zhao, 2010) and ammonium carbonate in water (Tamaddon et al. 2010). It is worth mentioning that many of these existing methods displayed drawbacks, such as environmental pollution caused by utilizing catalysts in stoichiometric quantities, exotic reaction conditions, unsatisfactory yields and complicated operations while other possess some advantages overcoming these drawbacks. Nickel nitrate hexahydrate is a convenient and widely used catalyst for affecting a broad spectrum of synthetic transformations because it has many advantages such as: solubility in water, inexpensive, eco-friendly nature, simplicity in handling and convenient work up (Boumoud et al., 2012).

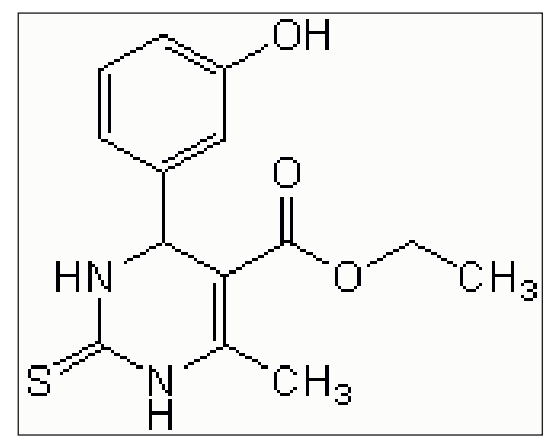

Fig. 1. Monastrol

In continuation of our interest in the synthesis of fused pyrimidines (Akhter et al., 2015), we report herein a simple, efficient procedure for one-pot synthesis of 3,4 -dihydropyrimidin-2 $(1 H)$-thiones derivatives $4 \mathrm{a}-\mathrm{f}$ using $\mathrm{Ni}\left(\mathrm{NO}_{3}\right)_{2} \cdot 6 \mathrm{H}_{2} \mathrm{O}$ as a catalyst under solvent free conditions through Biginelli reactions (Scheme 1). The synthesized compounds were evaluated for in vitro antimicrobial activity against Staphylococcus aureus, Bacillus cereus (gram +ve), Escherichia coli, Salmonella typhimerium (gram-ve) using KIRBY-BAUER method (Bauer et al., 1966). The primary purpose of the study was to evaluate antimicrobial potency of synthetic products against the particular bacteria.

\section{Materials and methods}

All products were characterized by their mp, IR, ${ }^{1} \mathrm{H}-\mathrm{NMR}$, ${ }^{13} \mathrm{C}$-NMR and elemental analyses. Thin layer chromatography (TLC) was carried out on plates percolated with silica gel $60 \mathrm{~F}_{254}$ (E.Merck) and spots were detected with iodine vapour. Melting points were determined on an Electro thermal micro melting point apparatus and uncorrected. IR spectra were recorded as $\mathrm{KBr}$ pellet using Shimadzu IR-470A spectrophotometer. The ${ }^{1} \mathrm{H}-\mathrm{NMR}$ was taken in DMSO- $\mathrm{d}_{6}$ and ${ }^{13} \mathrm{C}-\mathrm{NMR}$ spectra were taken in DMSO with TMS as an internal standard in Bruker 400 $\mathrm{MHz}$ spectrophotometer. The elemental analyses were done using PerkinElmer 2400 CHN Analyzer.

\section{General procedure for the synthesis of derivatives, $4 a-f$}

A mixture of an appropriate aldehyde, 1 (10 mmol), ethylacetoacetate, $2(10 \mathrm{mmol})$ and 1-phenyl-2-thiourea, 3 $(4.5 \mathrm{mmol})$ in the presence of $\mathrm{Ni}\left(\mathrm{NO}_{3}\right)_{2} \cdot 6 \mathrm{H}_{2} \mathrm{O}(10 \mathrm{~mol} \%)$ was heated $\left(70^{\circ} \mathrm{C}\right)$ within $8-11 \mathrm{~h}$; after completion of the reaction as indicated by TLC (eluting solvent, $\mathrm{CHCl}_{3}$ ), the reaction mixture was poured into ice water. A gummy product was obtained which was dissolved in absolute alcohol and filtered. The volume of the filtrate was then reduced to one-forth by rotary vacuum evaporator and the sample was transferred in a conical flask. Then the wall of the conical flask was scratched in an ice bath and a solid product was obtained; it was filtered and washed with cold absolute alcohol. The dried product was recrystallized with absolute alcohol to obtain the pure product.

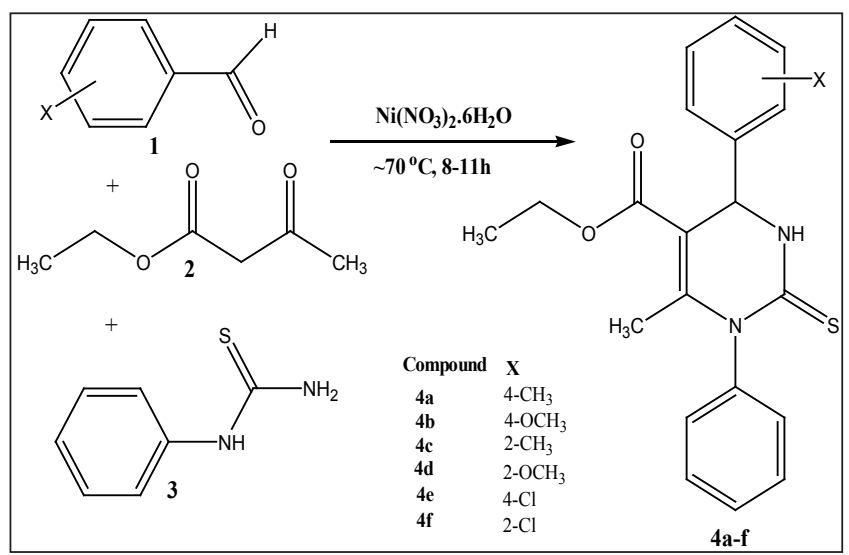

Scheme-1

6-Methyl-1-phenyl-2-thioxo-4-p-tolyl-1,2,3,4-tetrahydro-pyr imidine-5-carboxylic acid ethyl ester, $4 a$ :

Yield $87 \%$; white crystalline solid; m.p. $128^{\circ}-130^{\circ} \mathrm{C} ; \mathrm{R}_{\mathrm{f}}$ value: $0.52\left(\mathrm{CHCl}_{3}\right)$; IR $(\mathrm{KBr})\left(\mathrm{V}_{\max }, \mathrm{cm}^{-1}\right): 3180(\mathrm{~N}-\mathrm{H}) 3032$ (aromatic C-H stretching), 2835 (C-H stretching for $-\mathrm{CH}_{3}$ ), $1701 \quad(\mathrm{C}=\mathrm{O}$ stretching), $1631 \quad(>\mathrm{C}=\mathrm{C}<$ stretching in conjugation with $>\mathrm{C}=\mathrm{O}), 1492(\mathrm{C}=\mathrm{S}$ stretching $), 1344\left(-\mathrm{CH}_{3}\right.$ 
bending), 825 (aromatic $\mathrm{C}-\mathrm{H}$ bending); ${ }^{1} \mathrm{H}$ NMR $\delta$ (in ppm): 8.17 (s, 1H, NH, 3-H), 7.43-6.87 (m, 9H, arom), 5.40 (bs, 1H, 4-H), 4.12 (q, 2H, J=7.2, $\left.\mathrm{CH}_{3}-\mathrm{CH}_{2}-\mathrm{COO}-\right), 2.46(\mathrm{~s}, 3 \mathrm{H}$, $\left.\mathrm{C}_{3}-\mathrm{C}_{4}{ }^{\prime}\right), 2.15\left(\mathrm{~s}, 3 \mathrm{H}, \mathrm{CH}_{3}-\mathrm{C}_{6}=\mathrm{C}_{5}-\right), 1.19(\mathrm{t}, 3 \mathrm{H}, \mathrm{J}=7.2$, $\mathrm{CH}_{3}-\mathrm{CH}_{2}-\mathrm{COO}-$ ); ${ }^{13} \mathrm{C} \mathrm{NMR} \delta$ (in ppm): 178.46 (2-C), 165.73 $\left(\mathrm{CH}_{3}-\mathrm{CH}_{2}-\mathrm{COO}-\right), 145.90$ (6-C), 140.56 (C-1'), 139.31 (C-1"), 137.85 (C-4'), 129.51-126.31 (9C $\left.{ }_{\text {arom }}\right), 107.02$ (5-C), $60.58\left(\mathrm{CH}_{3}-\underline{\mathrm{CH}}_{2}-\mathrm{COO}-\right), 54.06$ (4-C), $21.09\left(\underline{\mathrm{CH}}_{3}-\mathrm{C}_{6} \mathrm{H}_{4}-\right)$, $18.59\left(\underline{\mathrm{CH}}_{3}-\mathrm{C}_{6}=\mathrm{C}_{5}-\right), 14.02\left(\underline{\mathrm{CH}}_{3} \mathrm{CH}_{2}-\mathrm{COO}-\right)$; Anal. Found: C, 68.78; H, 5.98; N, 7.02; Calcd. for $\mathrm{C}_{21} \mathrm{H}_{22} \mathrm{~N}_{2} \mathrm{O}_{2} \mathrm{~S}$ : C, 68.82; H, 6.05; N, 7.64\%.

4-(4-Methoxy-phenyl)-6-methyl-1-phenyl-2-thioxo-1,2,3,4-te trahydro-pyrimidine-5-carboxylic acid ethyl ester, $4 b$ :

Yield 90\%; white crystalline solid; m.p. $134^{\circ}-136^{\circ} \mathrm{C} ; \mathrm{R}_{\mathrm{f}}$ value: $0.50\left(\mathrm{CHCl}_{3}\right)$; IR $(\mathrm{KBr})\left(\mathrm{v}_{\max }, \mathrm{cm}^{-1}\right): 3398(\mathrm{~N}-\mathrm{H}) 3028$ (aromatic C-H stretching), $2922\left(\mathrm{C}-\mathrm{H}\right.$ stretching for $-\mathrm{CH}_{3}$ ), $1708 \quad(\mathrm{C}=\mathrm{O}$ stretching), $1635 \quad(>\mathrm{C}=\mathrm{C}<$ stretching in conjugation with $>\mathrm{C}=\mathrm{O}), 1442(\mathrm{C}=\mathrm{S}$ stretching $), 1342\left(-\mathrm{CH}_{3}\right.$ bending), 837, 761 (aromatic $\mathrm{C}-\mathrm{H}$ bending); ${ }^{1} \mathrm{H}$ NMR $\delta$ (in ppm): 8.12 (s, 1H, NH, 3-H), 7.43-7.15 (m, 9H $\left.{ }_{\text {arom }}\right) 5.42$ (bs, $1 \mathrm{H}, 4-\mathrm{H}), 4.13$ (q, 2H, J=7.2, $\left.\mathrm{CH}_{3}-\mathrm{CH}_{2}-\mathrm{COO}-\right)$, 3.79 (s, 3H, $\left.\mathrm{CH}_{3} \mathrm{O}-\mathrm{C}_{4}{ }^{\prime}\right), 2.09\left(\mathrm{~s}, 3 \mathrm{H}, \mathrm{CH}_{3}-\mathrm{C}_{6}=\mathrm{C}_{5}-\right), 1.20(\mathrm{t}, 3 \mathrm{H}, \mathrm{J}=6.9$, $\left.\mathrm{CH}_{3}-\mathrm{CH}_{2}-\mathrm{COO}-\right) ;{ }^{13} \mathrm{C} \mathrm{NMR} \delta$ (in ppm): 178.46 (2-C), 165.74 $\left(\mathrm{CH}_{3}-\mathrm{CH}_{2}\right.$-COO-), 159.38 (C-4'), 145.76 (6-C), 140.56 (C-1"), 134.52 (C-1'), 128.68-114.16 (9C $\mathrm{arom}), 107.10$ (5-C), $60.58\left(\mathrm{CH}_{3}-\underline{\mathrm{CH}_{2}}-\mathrm{COO}-\right), 55.25$ (4-C), $53.80\left(\underline{\mathrm{CH}}_{3} \mathrm{O}-\mathrm{C}_{4}{ }^{\prime}\right)$, $18.58\left(\underline{\mathrm{CH}}_{3}-\mathrm{C}_{6}=\mathrm{C}_{5}-\right), 14.08\left(\underline{\mathrm{CH}}_{3}-\mathrm{CH}_{2}-\mathrm{COO}-\right)$; Anal. Found: C, 65.91; H, 5.29; N, 7.17; Calcd. for $\mathrm{C}_{21} \mathrm{H}_{22} \mathrm{~N}_{2} \mathrm{O}_{3} \mathrm{~S}$ : C, 65.95; H, 5.80; N, 7.32\%.

6-Methyl-1-phenyl-2-thioxo-4-o-tolyl-1,2,3,4-tetrahydro-pyr imidine-5-carboxylic acid ethyl ester, $4 c$ :

Yield 92\%; white crystalline solid; m.p. $138^{\circ}-140^{\circ} \mathrm{C} ; \mathrm{R}_{\mathrm{f}}$ value: $0.50\left(\mathrm{CHCl}_{3}\right)$; IR $(\mathrm{KBr})\left(\mathrm{v}_{\max }, \mathrm{cm}^{-1}\right): 3188(\mathrm{~N}-\mathrm{H}) 3096$ (aromatic C-H stretching), 2985 (C-H stretching for $-\mathrm{CH}_{3}$ ), $1705\left(\mathrm{C}=\mathrm{O}\right.$ stretching), $1492(\mathrm{C}=\mathrm{S}$ stretching $), 1342\left(-\mathrm{CH}_{3}\right.$ bending), 825 (aromatic $\mathrm{C}-\mathrm{H}$ bending); ${ }^{1} \mathrm{H}$ NMR $\delta$ (in ppm): $7.54(\mathrm{~s}, 1 \mathrm{H}, \mathrm{NH}, 3-\mathrm{H}), 7.46-7.16\left(\mathrm{~m}, 9 \mathrm{H}_{\text {arom }}\right), 5.68(\mathrm{~d}$, $\mathrm{J}=2.4,1 \mathrm{H}, 4-\mathrm{H}), 4.02$ (q, 2H, J=6.9, $\left.\mathrm{CH}_{3}-\mathrm{CH}_{2}-\mathrm{COO}-\right)$, 2.46 (s, $\left.3 \mathrm{H}, \mathrm{CH}_{3}-\mathrm{C}_{6} \mathrm{H}_{4}-\right), 2.15\left(\mathrm{~s}, 3 \mathrm{H}, \mathrm{CH}_{3}-\mathrm{C}_{6}=\mathrm{C}_{5}-\right), 1.05(\mathrm{t}, 3 \mathrm{H}, \mathrm{J}=6.9$, $\mathrm{CH}_{3}-\mathrm{CH}_{2}-\mathrm{COO}-$ ); ${ }^{13} \mathrm{C}$ NMR $\delta$ (in ppm): 177.70 (2-C), 165.60 $\left(\mathrm{CH}_{3}-\mathrm{CH}_{2}-\mathrm{COO}-\right), 146.05$ (6-C), 140.74 (C-1'), 139.58 (C-1"), 135.06 (C-2'), 130.99 -126.86 (9C arom $), 105.81$ (5-C), $60.48\left(\mathrm{CH}_{3}-\underline{\mathrm{CH}}_{2}-\mathrm{COO}-\right), 51.93$ (4-C), $19.13\left(\underline{\mathrm{CH}}_{3}-\mathrm{C}_{6} \mathrm{H}_{4}^{-}\right)$, $18.63\left(\underline{\mathrm{CH}}_{3}-\mathrm{C}_{6}=\mathrm{C}_{5}-\right), 13.87\left(\underline{\mathrm{CH}}_{3} \mathrm{CH}_{2}-\mathrm{COO}-\right)$; Anal. Found: C, 68.72; H, 6.23; N, 7.15; Calcd. for $\mathrm{C}_{21} \mathrm{H}_{22} \mathrm{~N}_{2} \mathrm{O}_{2} \mathrm{~S}$ : C, 68.82; H, 6.05; N, 7.64\%.
4-(2-Methoxy-phenyl)-6-methyl-1-phenyl-1,2,3,4-tetrahydro -pyrimidine-5-carboxylic acid ethyl ester, $4 d$ :

Yield 82\%; white crystalline solid; m.p. $148^{\circ}-150^{\circ} \mathrm{C} ; \mathrm{R}_{\mathrm{f}}$ value: $0.53\left(\mathrm{CHCl}_{3}\right)$; IR $(\mathrm{KBr})\left(\mathrm{v}_{\max }, \mathrm{cm}^{-1}\right): 3219(\mathrm{~N}-\mathrm{H}) 3022$ (aromatic C-H stretching), $2933\left(\mathrm{C}-\mathrm{H}\right.$ stretching for $\left.-\mathrm{CH}_{3}\right)$, $1701\left(\mathrm{C}=\mathrm{O}\right.$ stretching), $1468\left(\mathrm{C}=\mathrm{S}\right.$ Stretching), $1340\left(-\mathrm{CH}_{3}\right.$ bending), 873 (aromatic $\mathrm{C}-\mathrm{H}$ bending); ${ }^{1} \mathrm{H}$ NMR $\delta$ (in ppm): $7.63(\mathrm{~s}, 1 \mathrm{H}, \mathrm{NH}, 3-\mathrm{H}), 7.41-6.91\left(\mathrm{~m}, 9 \mathrm{H}_{\text {arom }}\right), 5.78$ (d, J=2.1, $1 \mathrm{H}, 4-\mathrm{H}), 4.09$ (q, 2H, J=7.2, $\left.\mathrm{CH}_{3}-\mathrm{CH}_{2}-\mathrm{COO}-\right), 3.9(\mathrm{~s}, 3 \mathrm{H}$, $\left.\mathrm{C}_{6} \mathrm{H}_{4}-\mathrm{OCH}_{3}\right), 2.20\left(\mathrm{~s}, 3 \mathrm{H}, \underline{\mathrm{H}}_{3} \mathrm{C}-\mathrm{C}_{6}=\mathrm{C}_{5}-\right), 1.10(\mathrm{t}, 3 \mathrm{H}, \mathrm{J}=7.2$, $\left.\mathrm{CH}_{3}-\mathrm{CH}_{2}-\mathrm{COO}-\right) ;{ }^{13} \mathrm{C} \mathrm{NMR} \delta$ (in ppm): 178.27 (2-C), 165.78 ( $\mathrm{CH}_{3}-\mathrm{CH}_{2}$ - $\left.\underline{\mathrm{COO}}-\right), 156.89$ (C $\left.{ }_{2}{ }^{\prime}\right), 147.68$ (6-C), 140.68 (C-1"), 129.56 (C-1'), 128.97-110.92 (9C $\mathrm{Carom}), 104.29$ (5-C), 60.48 $\left(\mathrm{CH}_{3}-\underline{\mathrm{CH}}_{2}-\mathrm{COO}-\right), 55.56$ (4-C), $49.36\left(\underline{\mathrm{CH}}_{3} \mathrm{O}-\mathrm{C}_{4}{ }^{\prime}\right), 18.57$ $\left(\underline{\mathrm{CH}}_{3}-\mathrm{C}_{6}=\mathrm{C}_{5}-\right), 14.02$ ( $\left.\underline{\mathrm{CH}}_{3}-\mathrm{CH}_{2}-\mathrm{COO}-\right)$; Anal. Found: C, 65.93; H, 5.39; N, 7.11; Calcd. for $\mathrm{C}_{21} \mathrm{H}_{22} \mathrm{~N}_{2} \mathrm{O}$ S: C, 65.95; $\mathrm{H}$, $5.80 ; \mathrm{N}, 7.32 \%$.

4-(4-Chloro-phenyl)-6-methyl-1-phenyl-1,2,3,4-tetrahydro -pyrimidine-5-carboxylic acid ethyl ester, 4e:

Yield 80\%; white crystalline solid; m.p. $124^{\circ}-126^{\circ} \mathrm{C} ; \mathrm{R}_{\mathrm{f}}$ value: $0.49\left(\mathrm{CHCl}_{3}\right)$; IR $(\mathrm{KBr})\left(\mathrm{v}_{\max }, \mathrm{cm}^{-1}\right): 3176(\mathrm{~N}-\mathrm{H}), 3030$ (aromatic $\mathrm{C}-\mathrm{H}$ stretching), $1710(\mathrm{C}=\mathrm{O}$ stretching), 1635 $(>\mathrm{C}=\mathrm{C}<$ stretching in conjugation with $>\mathrm{C}=\mathrm{O}), 1445(\mathrm{C}=\mathrm{S}$ Stretching), 1382 (- $\mathrm{CH}_{3}$ bending), 1082 (C-Cl stretching), 837, 690 (aromatic C-H bending); ${ }^{1} \mathrm{H}$ NMR $\delta$ (in ppm): 8.37 $(\mathrm{s}, 1 \mathrm{H}, \mathrm{NH}, 3-\mathrm{H}), 7.51-7.02\left(\mathrm{~m}, 9 \mathrm{H}_{\text {arom }}\right), 5.43(\mathrm{~d}, \mathrm{~J}=3.2,1 \mathrm{H}$, 4-H), 4.13 (q, 2H, J=7.2, $\mathrm{CH}_{3}-\underline{\mathrm{CH}}_{2}-\mathrm{COO}$ ), 2.09 (s, 3H, $\left.\mathrm{CH}_{3}-\mathrm{C}_{6}=\mathrm{C}_{5}-\right), 1.19\left(\mathrm{t}, 3 \mathrm{H}, \mathrm{J}=7.2, \underline{\mathrm{CH}}_{3}-\mathrm{CH}_{2}-\mathrm{COO}-\right) ;{ }^{13} \mathrm{C}$ NMR $\delta$ (in ppm): 178.46 (2-C), $165.52\left(\mathrm{CH}_{3}-\mathrm{CH}_{2}-\mathrm{COO}-\right)$, 146.49 (6-C), 140.71 (C-1'), 140.32 (C-1"), 133.98 (C-4'), 129.03-127.83 (9C $\left.\mathrm{C}_{\text {arom }}\right), 106.56(5-\mathrm{C}), 60.76$ ( $\left.\mathrm{CH}_{3}-\underline{\mathrm{CH}}_{2}-\mathrm{COO}-\right)$, 53.61 (4-C), $18.66\left(\underline{\mathrm{CH}}_{3}-\mathrm{C}_{6}=\mathrm{C}_{5}-\right), 14.02\left(\underline{\mathrm{CH}}_{3}-\mathrm{CH}_{2}-\mathrm{COO}-\right)$; Anal. Found: C, 61.97; H, 4.26; N, 6.99; Calcd. for $\mathrm{C}_{20} \mathrm{H}_{19} \mathrm{ClN}_{2} \mathrm{O}_{2} \mathrm{~S}: \mathrm{C}, 62.09 ; \mathrm{H}, 4.95 ; \mathrm{N}, 7.24 \%$.

4-(2-Chloro-phenyl)-6-methyl-1-phenyl-1,2,3,4-tetrahydro-p yrimidine-5-carboxylic acid ethyl ester, $4 f$ :

Yield $86 \%$; white crystalline solid; m.p. $142^{\circ}-144^{\circ} \mathrm{C}$; $\mathrm{R}_{\mathrm{f}}$ value: $0.65\left(\mathrm{CHCl}_{3}\right)$; IR (KBr) $\left(\mathrm{v}_{\max }, \mathrm{cm}^{-1}\right): 3486(\mathrm{~N}-\mathrm{H}), 3034$ (arom. C-H stretching), 2927 (C-H stretching for $\left.-\mathrm{CH}_{3}\right), 1708(\mathrm{C}=\mathrm{O}$ stretching), 1447 ( $\mathrm{C}=\mathrm{S}$ stretching), 1352 ( $-\mathrm{CH}_{3}$ bending), 1085 (C-Cl stretching), 823, 754 (arom. C-H bending); ${ }^{1} \mathrm{H}$ NMR $\delta$ (in ppm): $7.51(\mathrm{~s}, 1 \mathrm{H}, \mathrm{NH}, 3-\mathrm{H}), 7.42-7.11\left(\mathrm{~m}, 9 \mathrm{H}_{\text {arom. }}\right), 5.91$ (bs, $1 \mathrm{H}, 4-\mathrm{H}$ ), 4.04 (q, 2H, J=5.6, $\mathrm{CH}_{3}-\mathrm{CH}_{2}-\mathrm{COO}-$ ), 2.22 (bs, $\left.3 \mathrm{H}, \mathrm{CH}_{3}-\mathrm{C}_{6}=\mathrm{C}_{5}-\right), 1.06\left(\mathrm{t}, 3 \mathrm{H}, \mathrm{J}=5.8, \mathrm{C}_{3}-\mathrm{CH}_{2}-\mathrm{COO}-\right) ;{ }^{13} \mathrm{C}$ NMR $\delta^{-}$(in ppm): $178.43(2-\mathrm{H}), 165.25\left(\mathrm{CH}_{3}-\mathrm{CH}_{2}-\mathrm{COO}-\right)$, 147.90 (6-C), 140.53 (C-1'), 138.01 (C-1"), 132.94 (C-2'), 
$130.20-127.60\left(9 \mathrm{C}_{\text {arom }}\right), 104.24$ (5-C), 60.60 ( $\left.\mathrm{CH}_{3}-\mathrm{CH}_{2}-\mathrm{COO}-\right)$, 51.57 (4-C), $18.55\left(\underline{\mathrm{CH}}_{3}-\mathrm{C}_{6}=\mathrm{C}_{5}-\right), 13.86\left(\underline{\mathrm{CH}_{3}}-\mathrm{CH}_{2}-\mathrm{COO}-\right)$; Anal. Found: C, 61.99; H, 4.77; N, 7.21; Calcd. for $\mathrm{C}_{20} \mathrm{H}_{19} \mathrm{ClN}_{2} \mathrm{O}_{2} \mathrm{~S}$ : C, 62.09; H, 4.95; N, 7.24\%.

\section{In Vitro antimicrobial activity (Microorganisms and media) (CLSI 2012)}

The test organisms used in this study were as follows: Bacillus cereus (ATCC 19637), Staphylococcus aureus (Coagulate), Escherichia coli (ATCC 20120829) and Salmonella typhimerium (JCM-1692). Routine culture was performed on Tryptone Soya Broth $\left(\mathrm{pH} 7.3 \pm 0.2\right.$ at $\left.25^{\circ} \mathrm{C}\right)$ in a required number of inoculation tube. 5 falcon tubes containing $5 \mathrm{ml}$ nutrient rich media each was inoculated through sterilized loop tip with each isolated bacteria strain. The incubation of the strain for the antimicrobial test was executed in an aerobic chamber at $37^{\circ} \mathrm{C}$ in an incubator for 24 hours. After that the growth was checked by a cloudy haze in the media. Test sample were prepared in DMSO with concentration $1 \mathrm{mg} / \mathrm{ml}$.

\section{Results and discussion}

Initially we studied a model reaction employing benzaldehyde, ethyl acetoacetate and 1-phenyl thiourea in the presence of four different molar ratios of $(2,5,10$ and 15 mol\%) in order to investigate the catalytic efficiency of $\mathrm{Ni}\left(\mathrm{NO}_{3}\right)_{2} \cdot 6 \mathrm{H}_{2} \mathrm{O}$ to establish the optimum quantity of this catalyst and our study has revealed that $10 \mathrm{~mol} \%$ of the catalyst as the optimum ratio. The structures of the compounds $4 \mathrm{a}-\mathrm{f}$ were confirmed with the help of their IR, ${ }^{1} \mathrm{H}-\mathrm{NMR}$ and ${ }^{13} \mathrm{C}-\mathrm{NMR}$ spectral data and elemental analyses.

The IR spectral data of the compounds $4 \mathrm{a}-\mathrm{f}$ shows the wave number. The functional groups of the compounds have been confirmed by the peaks. For example, peaks for $\mathrm{N}-\mathrm{H}$ stretching were found in between $3180-3486 \mathrm{~cm}^{-1}, \mathrm{C}=\mathrm{O}$ stretching of esters were found in between $1701-1710 \mathrm{~cm}^{-1}$, $\mathrm{C}=\mathrm{C}$ in conjugation with $\mathrm{C}=\mathrm{O}$ were found in between 1631-1635 $\mathrm{cm}^{-1}, \mathrm{C}=\mathrm{S}$ stretching were found in between $1442-1492 \mathrm{~cm}^{-1}$ and $\mathrm{C}-\mathrm{Cl}$ were found in $1082-1085 \mathrm{~cm}^{-1}$.

The ${ }^{1} \mathrm{H}-\mathrm{NMR}$ spectral data shows the presence of all the protons attached to carbons in the compounds, 4a-f. A slight variation in the positions of $\mathrm{N}-\mathrm{H}$ protons were observed at $\delta$ 7.51-8.37 ppm may be due the change in the substituents on the benzene ring from para position to ortho position. The methoxy groups, in which the methyl group being attached to an electronegative oxygen atom were slightly deshielded with a chemical shift $\delta 3.79-3.90$ ppm than the methyl group ( $\delta$ $2.46 \mathrm{ppm}$ ). Two other methyl groups were distinguished from

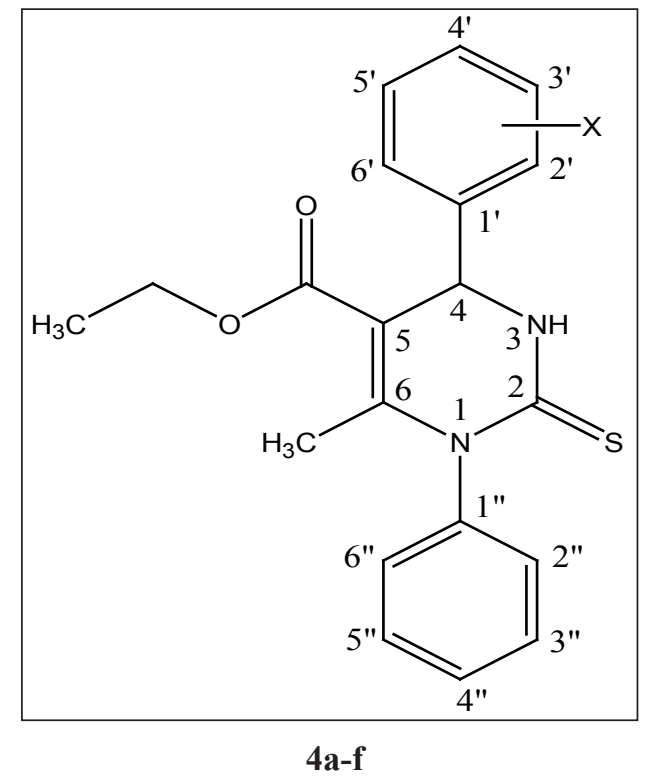

each other by their attachment to neighbouring atoms. Methyl protons attached to an alkene carbons gave peaks at $\delta 2.09-2.22$ ppm and another methyl protons attached to an ester and a methylene group gave peaks in a shielded region at $\delta 1.05-1.20$ $\mathrm{ppm}$. The methylene protons being attached to a methyl in one side and an ester on the other side further deshielded due to direct link with one oxygen of ester group and gave peaks at $\delta$ $4.02-4.13 \mathrm{ppm}$. The proton at position 4 appeared as a doublet (or broad singlet) due to the vicinal coupling with the proton at position 3. The chemical shifts were observed at $\delta 5.40-5.91$ ppm. All aromatic protons have shown peaks in their expected positions.

The structures of the compounds, 4a-f were further confirmed with their ${ }^{13} \mathrm{C}-\mathrm{NMR}$ spectra. The $2-\mathrm{C}$ carbons being attached to an electronegative sulphur atom on one side and nitrogen atom on other side gave peaks at a highly deshielded region $(\delta$ $177.70-178.46 \mathrm{ppm})$. The ester carbons attached to ethyl group were deshielded and gave peaks at $\delta 165.25-165.78 \mathrm{ppm}$. The methyne carbons at $4-C$ gave a peak at $\delta 51.57-55.56 \mathrm{ppm}$. One of the alkene carbons (5-C) gave peak at $\delta 104.24-107.10 \mathrm{ppm}$ and the other one (6-C) at $\delta 145.76-147.90 \mathrm{ppm}$. The substituents in the benzene ring $\left(-\mathrm{OCH}_{3}\right.$ and $\left.-\mathrm{CH}_{3}\right)$ showed slight variations in their peaks due to their attachment with an electronegative oxygen atom, resulting the methoxy carbon $(\delta$ 49.36-53.80 ppm) more deshielded than the methyl carbon $(\delta$ 19.13-21.09 ppm). The methyl and methylene carbons attached to ester gave peaks at $\delta 13.86-14.08 \mathrm{ppm}$ and $\delta$ 60.60-60.48 ppm respectively. The methyl carbons attached to 6-C gave peaks at 18.55-18.66 ppm. All aromatic carbons have shown peaks in their expected positions. 
Although different mechanistic pathways have been proposed previously (Tamaddon et al., 2010; Murata et al., 2010; Nagarajaiah et al., 2016; Murthy et al., 2016), we believe that the reaction may proceed through an initially formed to the prepared petry plate (containing $20 \mathrm{ml}$ Tryptone Soya Agar, $\mathrm{pH} 7.4$ in each plate) with a wet swab containing the bacterial broth culture. The synthetic compounds impregnated disks were placed on the surface of the agar,

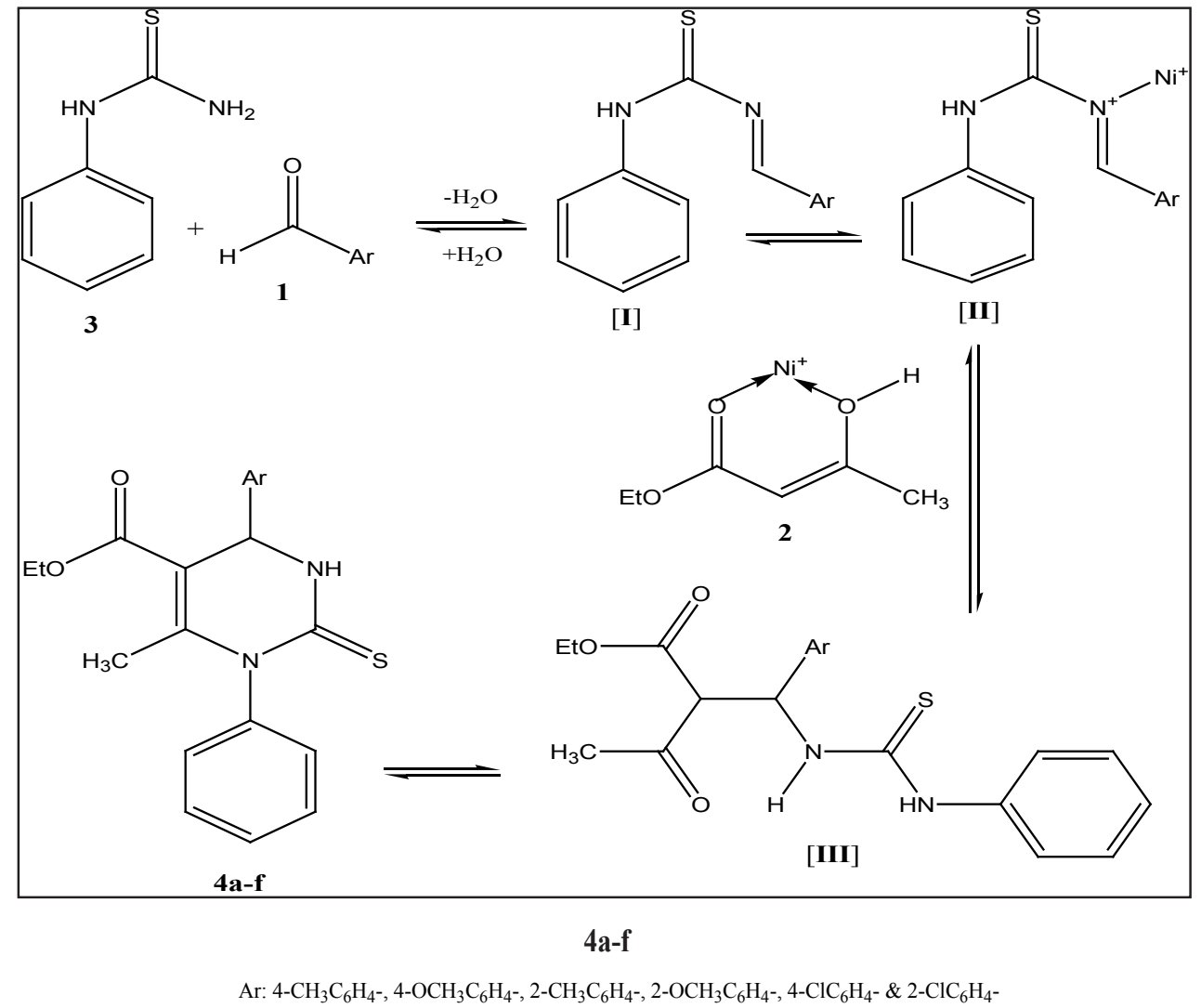

Scheme-2: The probable reaction pathway of the compounds, 4a-f

imine intermediate [I] from the reaction of the aldehyde, 1 and 1-phenyl thiourea, 3 (Scheme-2). The co-ordination of the lone pair of the nitrogen atom with the Lewis acid could lead to the in situ formation of iminum ion [II] which is sufficient electrophile to react with the enol form of ethyl acetoacetate, 2 affording the open chain intermediate [III]. Finally, intramolecular cyclization with loss of $\mathrm{H}_{2} \mathrm{O}$ molecule, producing the 3 , 4-dihydropyrimidin-2(1H) - thiones, 4a-f.

\section{Microbial test for the compounds, 4a-f}

Susceptibility tests were performed by the disk diffusion method of Bauer et. al. Zone of inhibition were measured after $24 \mathrm{~h}$ of incubation. Commercial antibiotic (Nalidixic acid) was used as controls. Bacteria were transferred directly using forceps. In each $100 \mathrm{~mm}$ plate 5 disks were placed for individual kind of bacteria. All plates then incubated at $37^{\circ} \mathrm{C}$ overnight. Zone of inhibition were measured on the underside of the plates with a metric ruler. Five zone diameters for particular compounds were records on different plates. The disk potency and their zone of inhibition were summarized in the following table (Table-I):

Compounds 4a, 4c-d and 4f showed strong (18 mm Z.D.) inhibitory activity for Bacillus cereus compared with Nalidixic acid (15 mm). Compounds $4 \mathrm{~b}$ and $4 \mathrm{e}$ showed intermediate inhibitory activity for Bacillus cereus. Compounds $4 \mathrm{a}-\mathrm{f}$ were found to be resistant for strain of Staphylococcus aureus, Escherichia coli and Salmonella typhimerium. 
Table I. Antimicrobial Test Data For Compounds, 4a-f

\begin{tabular}{|c|c|c|c|c|c|}
\hline \multirow[b]{2}{*}{ Compound } & \multirow{2}{*}{$\begin{array}{l}\text { Disk } \\
\text { potency } \\
\text { g/mL }\end{array}$} & \multicolumn{4}{|c|}{ Zone of inhibition in $\mathrm{mm}$} \\
\hline & & S. aureus & E. coli & S. typhimerium & B. cereus \\
\hline $4 a$ & 30 & 6 & 6 & 6 & 18 \\
\hline $4 b$ & 30 & 6 & 6 & 6 & 17 \\
\hline $4 c$ & 30 & 6 & 6 & 6 & 18 \\
\hline $4 d$ & 30 & 6 & 6 & 6 & 18 \\
\hline $4 e$ & 30 & 6 & 6 & 6 & 17 \\
\hline $4 f$ & 30 & 6 & 6 & 6 & 18 \\
\hline $\begin{array}{l}\text { Standard } \\
\text { control }\end{array}$ & 30 & 19 & 19 & 20 & 15 \\
\hline
\end{tabular}

Table-II. Summerized Data of Antimicrobial Properties of Compounds, 4a-f

\begin{tabular}{lllll}
\hline Compound & S. aureus & E. coli & S. typhimerium & B. cereus \\
\hline $\mathbf{4 a}$ & Resistant & Resistant & Resistant & Susceptible \\
$\mathbf{4 b}$ & Resistant & Resistant & Resistant & Intermediate \\
$\mathbf{4 c}$ & Resistant & Resistant & Resistant & Susceptible \\
$\mathbf{4 d}$ & Resistant & Resistant & Resistant & Susceptible \\
$\mathbf{4 e}$ & Resistant & Resistant & Resistant & Intermediate \\
$\mathbf{4 f}$ & Resistant & Resistant & Resistant & Susceptible \\
\hline
\end{tabular}

\section{Conclusion}

With the aim for the development of environmentally friendly new technique, we have successfully developed an easy, high yielding and versatile protocol for the synthesis of 1-phenyl-3, 4-dihydropyrimidin-2(1H)-thiones from the reaction of aryl aldehydes, ethyl acetoacetate, 1-phenyl thiourea catalyzed by Nickel nitrate hexahydrate. As per literature review, this is a new and simple technique of high atom economy with good yields. Most of the synthesized compounds showed good to moderate antimictrobial activity against Bacillus cereus. Kirby Bauer disc-diffusion test demonstrated the result for the $30 \mu \mathrm{g}$ concentration of particular compound, $4 \mathrm{a}-\mathrm{f}$ are summarized in (Table-II).

\section{References}

Akhter K, Jahan K, Romman UKR, Ahmed MG, Rahman MS and Amin MA (2015), A Green Approach to
Synthesize Dihydropyrimidinone derivatives by using anhydrous $\mathrm{ZnCl}_{2}$ catalyst under refluxing condition in heptane-toluene medium vi Biginelli reaction, Asian $J$. Chem. 27: 2624-2626.

Azizian J, Mohammadi AA, Karimi AR and Mohammadizadeh MR (2006), $\mathrm{KAl}\left(\mathrm{SO}_{4}\right) \cdot 12 \mathrm{H}_{2} \mathrm{O}$ supported on silica gel as a novel heterogeneous system catalyzed Biginelli reaction: one-pot synthesis of dihydropyrimidinones under solvent-free conditions, Appl. Catal. A. 300: 85-88. doi.org/10.1016/j.apcata.2005.11.001

Bauer AW, Kirby WMM, Sherris JC and Turck M (1966), Antibiotic susceptibility testing by a standardized disk method. Amer. J. Clin. Path. 45: 493-496. doi.org/10.1093/ajcp/45.4_ts.493

Biginelli P (1893), Derivati aldeiduredici degli eteri acetile dossal-acetico, Gazz. Chim. Ital. 23: 360-416. 
Boumoud B, Yahiaoui AA, Boumoud T and Debache A (2012), A novel catalyst for one-pot synthesis of tetrahydrobenzo $[b]$ pyran derivatives, J. Chem. Pharm. Res. 4: 795-799.

Chitra S and Pandiarajan K (2009), Calcium Fluoride: An efficient and reusable catalyst for the synthesis of 3, 4dihydropyrimidin-2(1H)-ones and their corresponding 2-(1H)-thiones: an improved high yielding protocol for Biginelli reaction, Tetrahedron Lett. 50: 2222-2224. doi.org/10.1016/j.tetlet.2009.02.162

Cho H, Ueda M, Shima K, Mizuno A, Hayashimatsu M, Ohnaka Y, Takeuchi Y, Hamaguchi M and Aisaka K (1989), Dihydropyrimidines: Novel calcium antagonists with potent and long-lasting vasodilative and anti-hypertensive activity, J. Med. Chem. 32: 2399-2406. DOI: 10.1021/jm00130a029

CLSI (2012), Performance standards for antimicrobial disk susceptibility tests, Approved Standard, $7^{\text {th }}$ Ed., CLSI document M02-A11. Clinical and Laboratory Standards Institute, 950 West Valley Road, Suite 2500, Wayne, Pennsylvania 19087, USA.

Debache A, Amimour M, Belfaitah A, Rhouati S and Carboni B (2008), A one-pot Biginelli synthesis of 3, 4-dihydropyrimidin-2(1H)-ones/thiones catalyzed by triphenyl phosphine as Lewis base, Tetrahedron Lett. 49: 6119-6121. doi.org/10.1016/j.tetlet.2008.08.016

Ding D and Zhao CG (2010), Primary amine catalyzed Biginelli reaction for the enantioselective synthesis of 3,4-dihydropyrimidin-2(1H)-ones, Eur. J. Org. Chem. 2010: 3802- 3805. https://doi.org/10.1002/ ejoc. 201000448

Dondoni A, Massi A and Sabbatini S (2002), Improved synthesis and preparative scale resolution for racemic monastrol, Tetrahedron Lett. 43: 5913-5916. doi.org/10.1016/S0040-4039(02)01269-8

Mirzaei YR, Azamat H and Namazi H (2001), Investigation the reactivity of positions N-3, C-5 and C6-methyl group in Biginelli type compounds and synthesis of new dihydropyrimidine derivatives, J. Heterocycl. Chem. 38: 1051-1054.

Mandhane PG, Joshi RS, Nagargoje DR and Gill CH (2010), An efficient synthesis of 3,4-dihydropyrimidin$2(1 H)$-ones catalyzed by thiamine hydrochloride in water under ultrasound irradiation, Tetrahedron Lett., 51: 3138-3140.

Murata H, Ishitani H, Iwamoto M (2010), Synthesis of Biginelli dihydropyrimidinone derivatives with various substituents on aluminium-planted mesoporous silica catalyst, Org. Biomol. Chem. 8: 1202-1211. DOI:10.1039/B920821F

Murthy YLN, Rajack A and Yuvaraj K (2016), Solvent free synthesis of 3,4-dihydropyrimidine-2 -(1H)ones/thiones catalyzed by N,O-bis (trimethylsilyl) acetamide and dicyclohexyl carbodimide, Arabian $J$. Chem. 9: S1740-S1746.

Nagarajaiah H, Mukhopadhyay A, Moorthy JN (2016), Biginelli reaction: an overview, Tetrahedron Lett. 57: 5135-5149.

Paraskar AS, Dewkar GK and Sudalai A (2003), Cu(OTf) : A reusable catalyst for high-yield synthesis of 3,4-di-hydropyrimidin-2(1H)-ones, Tetrahedron Lett. 44: 3305-3308.

Pasunooti KK, Chai H, Jensen CN, Gorityala BK, Wang S and Liu XW (2011), A microwave-assisted, copper catalyzed three-component synthesis of dihydropyrimidinones under mild conditions, Tetrahedron Lett. 52: 80-84.

Patil S, Jodhav SD and Deshmukh MB (2011), Natural acid catalyzed multi-component reactions as a green approach, Arch. Appl. Sci. Res. 3: 203-208.

Rovnyak GC, Kimball SD, Beyer B, Cucinotta G, DiMarco JD, Gougoutas J, Hedberg A, Malley M, McCarthy JP, Zhang R and Moreland SJ (1995), Calcium entry blockers and activators: conformational and structural determinants of dihydro-pyrimidine calcium channel modulators, J. Med. Chem. 38: 119-129. DOI: 10.1021/jm00001a017

Sabitha G, Reddy KB, Yadav JS, Shailaja D and Sivudu KS (2005), Ceria/vinyl pyridine polymer nanocomposite: an ecofriendly catalyst for the synthesis of 3,4-dihydropyrimidin-2(1H)-ones, Tetrahedron Lett. 46: 8221-8222. doi.org/10.1016/j.tetlet.2005.09.100

Sadek KU, Al-Qalaf F, Khalik MMA and Elnagdi $\mathrm{MH}$ (2010), Cerium (IV) ammonium nitrate as an efficient lewis acid for one-pot synthesis of 3,4-dihydropyrimidin-2(1H)-ones and their 
corresponding 2(1H)-thiones, J. Heterocycl. Chem. 47: 284-286. doi.org/10.1002/jhet.259

Salim SD and Akamanchi KG (2011), Sulfated Tungstate: An alternative, eco-friendly catalyst for Biginelli reaction, Catal. Commun. 12: 1153-1156. doi.org/10.1016/j.catcom.2011.02.018

Shaaban MR, Saleh TS, Mayhoub AS, Mansour A and Farag AM (2008), Synthesis and analgesic/ anti-inflammatory evaluation of fused heterocyclic ring systems incorporating phenylsulfonyl moiety, Bioorg. Med. Chem. 16: 6344-6352. doi.org/ 10.1016/j.bmc.2008.05.011

Shapiro N and Vigalok A (2008), Highly efficient organic reactions 'on water' and 'in water' and both, Angew. Chem. Int. Ed. 120: 2891-2894. doi.org/ 10.1002/ anie. 200705347

Shen ZL, Xu XP and Ji SJ (2010), Bronsted Base-Cata- lyzed One-Pot Three Component Biginelli Type Reaction: An efficient synthesis of 4,5,6-triaryl-3, 4dihydropyrimidin-2(1H)-one and mechanistic study, $J$. Org. Chem. 75: 1162-1167. DOI: 10.1021/jo902394y
Snider BB and Shi Z (1993), Biomimetic synthesis of (.+-.) crambines $\mathrm{A}, \mathrm{B}, \mathrm{C} 1$ and $\mathrm{C} 2$. Revision of the structure of crambines B and C1, J. Org. Chem. 58: 3828-3839.

Tamaddon F, Razmi Z and Jafari AA (2010), Synthesis of 3, 4-dihydropyrimidin-2(1H)-ones and 1, 4-dihydropyridines using ammonium carbonate in water, Tetrahedron Lett. 51: 1187-1189. doi.org/10.1016/j.tetlet.2009.12.098

Tsuruo T, Iida H, Nojiri M, Tsukagoshi S and Sakurai Y (1983), Circumvention of vincristine and adriamycin resistance in vitro and in vivo by calcium blockers, Cancer Res. 43: 2905-2910.

Van Zandt MC, Jones ML, Gunn DE, Geraci LS, Jones JH, Sawicki DR, Sredy J, Jacot JL, Di-Cioccio AT, Petrova T, Mitschler A and Podjarny AD (2005), Discovery of 3-[(4,5,7- triflurobenzothiazol -2-yl) methyl] indole- $N$-acetic acid (lidorestat) and congeners as highly potent and selective inhibitors of aldose reeducates for treatment of chronic diabetic complications, J. Med. Chem. 48: 3141-3152. 